\section{A Rapid Method to Assess Grape Rust Mites on Leaves and Observations from Case Studies in Western Oregon Vineyards}

\author{
R. Paul Schreiner ${ }^{1,4}$, Patricia A. Skinkis ${ }^{2}$, and Amy J. Dreves ${ }^{3}$
}

AdDitional InDEX wORDs. Calepitrimerus vitis, Eriophyidae, extraction method, leaf stippling, scouting technique, Vitis vinifera

Summary. The grape rust mite [Calepitrimerus vitis (Acari: Eriophyidae)] is an important pest of grapevines (Vitis sp.) in grape-growing regions around the world. A rapid method for extracting eriophyoid mites was adapted from earlier studies to provide integrated pest management (IPM) consultants and commercial growers with a practical, efficient, and reliable tool to monitor grape rust mites in vineyards and nursery stock vines. The rinse in bag (RIB) method allows quick extraction of mites from young shoots or from leaves using $35 \%$ to $70 \%$ ethanol or isopropanol in a sealable plastic bag. The RIB method recovered $\approx \mathbf{8 5} \%$ of grape rust mites from single leaves in the first rinse. The method is useful to estimate grape rust mites on young shoots ( $\leq 10 \mathrm{~cm}$ length), although recovery of grape rust mites (average ranging from $35 \%$ to $81 \%$ ) was lower because of a higher density of trichomes on young shoots as compared with leaf samples. The RIB method was not effective to assess grape rust mites within dormant buds, so a separate method using a blender to disrupt tissues and extract mites in alcohol was developed. The RIB method was used to determine grape rust mite abundance with leaf symptoms in commercial vineyards and nursery stock vines. The earliest visible symptom of grape rust mite damage on leaves in the summer was the development of stippling that is distinct from the type of damage caused by other grapevine pests. The stippling is described as numerous clear zones of small diameter (resembling pinholes) that are visible when a leaf is backlit. The severity of stippling was related to the number of grape rust mites present on leaves, with $>600$ occurring on leaves with severe stippling symptoms. In commercial vineyard case studies, the RIB method was used over two seasons and revealed that grape rust mite populations remained on leaves until postharvest, and foliar applications of wettable sulfur reduced grape rust mite populations on leaves.

$\mathrm{T}$ The grape rust mite can attain high populations on grapevine shoots and leaves in Europe, Australia, and North and South America (Duso et al., 2010), where it feeds by inserting a stylet into epidermal layers of plant cells (Westphal and Manson, 1996). Grape rust mites overwinter

We thank Matthew Scott, Morgan Curtis, Karen
Peterson, and Alison Reeve for technical assistance,
and Allen Holstein, Jaime Cantu, Robert Schultz,
Luke Pedotti, and Ken Johnston for providing access
to vineyards, cooperating with sampling, and pro-
viding spray records at vineyards sampled.
Mention of trade names or commercial products in Mention of trade names or commercial products in
this publication is solely for the purpose of providing specific information and does not imply recommendation or endorsement by the U.S. Department of Agriculture.

${ }^{1}$ U.S. Department of Agriculture-Agriculture Research Service Horticultural Crops Research Laboratory, 3420 Northwest Orchard Avenue, Corvallis, OR 97330

${ }^{2}$ Department of Horticulture, Oregon State University, 4017 ALS Building, Corvallis, OR 97331

${ }^{3}$ Department of Crop and Soil Science, Oregon State University, 109 Crop Science Building, Corvallis, OR 97331

${ }^{4}$ Corresponding author. E-mail: Paul.Schreiner@ars. usda.gov. in and around individual dormant buds, and in the bark of older woody tissues (Bernard et al., 2005; PérezMoreno and Moraza-Zorrilla, 1998). The impact of grape rust mites on vine growth can be severe when very high populations ( $>500$ grape rust mites per shoot) are present early in the growing season and when cool temperatures in spring reduce the rate of shoot expansion (Bernard et al., 2005). Stunting of spring shoot growth is cultivar dependent, with fast growing cultivars being less affected by grape rust mite outbreaks. The pest status of the grape rust mite is unclear in some regions where infestation has not caused apparent damage to leaves or shoots (Duso et al., 2010) possibly because of different environmental conditions and the populations of predatory mites that feed on grape rust mites. Earlier research conducted in western Oregon suggested that very low numbers $(<10$ grape rust mites per shoot) may cause retarded spring shoot growth (Walton et al., 2007). However, subsequent sampling in numerous vineyards where spring shoot stunting occurred (2005 to 2009) revealed the absence of grape rust mites or grape bud mites (Colomerus vitis) on young shoots (R.P. Schreiner and P.A. Skinkis, unpublished data), suggesting that other factors can be responsible for restricted growth including winter freeze damage (Fennel, 2004), cool early season temperatures (Winkler et al., 1974), boron deficiency (Cook, 1966), herbicide damage (Bhatti et al., 1997), and high numbers of western flower thrips [Frankliniella occidentalis (McNally et al., 1985)].

More recently (2009 to 2012), a large number of newly planted vineyards in the Willamette Valley developed stunted, deformed, and often pubescent shoots during spring, and these stunted shoots had high numbers of grape rust mites ( $>500$ mites per shoot), similar to levels that caused stunting in Australian vineyards (Bernard et al., 2005). The high incidence of stunted shoots and presence of grape rust mites in newly planted vineyards in the region led producers to prophylactic use of early season miticides, including application of lime sulfur during wooly bud stage and budbreak, even though the presence of grape rust mites was not confirmed at most sites. Because of prior studies

\begin{tabular}{llll}
\hline $\begin{array}{l}\text { Units } \\
\begin{array}{l}\text { To convert U.S. to SI, } \\
\text { multiply by }\end{array}\end{array}$ & U.S. unit & SI unit & $\begin{array}{l}\text { To convert SI to U.S., } \\
\text { multiply by }\end{array}$ \\
\hline 29.5735 & $\mathrm{fl} \mathrm{oz}$ & $\mathrm{mL}$ & 0.0338 \\
0.3048 & $\mathrm{ft}$ & $\mathrm{m}$ & 3.2808 \\
9.3540 & gal/acre & $\mathrm{L} \cdot \mathrm{ha}^{-1}$ & 0.1069 \\
2.54 & inch $(\mathrm{es})$ & $\mathrm{cm}$ & 0.3937 \\
25.4 & inch $(\mathrm{es})$ & $\mathrm{mm}$ & 0.0394 \\
6.4516 & inch & $\mathrm{cm}^{2}$ & 0.1550 \\
1.1209 & lb/acre & $\mathrm{kg} \cdot \mathrm{ha}^{-1}$ & 0.8922 \\
1 & micron & $\mu \mathrm{m}$ & 1 \\
1 & $\mathrm{ppm}$ & $\mu \mathrm{L}^{-1} \mathrm{~L}^{-1}$ & 1 \\
$\left({ }^{\circ} \mathrm{F}-32\right) \div 1.8$ & ${ }^{\circ} \mathrm{F}$ & ${ }^{\circ} \mathrm{C}$ & $\left({ }^{\circ} \mathrm{C} \times 1.8\right)+32$
\end{tabular}


associating grape rust mite presence with spring stunting, many producers and consultants assumed that any spring growth abnormalities were caused by grape rust mites without verifying their presence. The lack of confirmation of pest presence was due in part to the difficulty in monitoring grape rust mites. As with many eriophyoid mites, monitoring grape rust mite populations in plant tissues is difficult because of their microscopic size $(80$ to $360 \mu \mathrm{m})$ and often-cryptic lifestyle (Monfreda et al., 2010).

At the same time that severe mite outbreaks occurred in vineyards, new grapevine plants received from nurseries or propagated from dormant canes collected from local vineyards developed stippling symptoms on leaves $(\approx 10 \%$ of vines $)$ shortly after plants were moved into the greenhouse, and these stippled leaves had moderate populations of grape rust mites (50 to 150 per leaf). A small percentage of vines $(\approx 3 \%)$ also developed stunted and unusually pubescent shoots where high numbers of grape rust mites were localized (>200 per shoot). Grape rust mites were extracted from these shoots and leaves using an ethanol washing technique [henceforth referred to as the spray and sieve (S\&S) method] and retrieved on a $25-\mu \mathrm{m}$ sieve as described by others (Pérez-Moreno and Moraza-Zorrilla, 1998; Zacharda et al., 1988). Fauna were then examined under a stereoscope. This method was shared with local producers who used it to monitor grape rust mites in a number of recently planted vineyards. However, after consultation with those producers, it became clear that a more efficient method was necessary. The overall goal of this research was to develop a practical, economical, and efficient technique to allow viticulturists and agricultural IPM consultants to assess grape rust mite populations. The rinse in bag method was developed to meet this need. Procedural aspects of the RIB method were examined and compared with both direct visual counts of mites on plant tissues and to ethanol extracts after disrupting tissues in a blender. The RIB method was also used to examine seasonal populations of grape rust mites in commercial vineyards and to establish the relationship of visual symptoms on leaves to grape rust mite abundance.

\section{Materials and methods}

ExPERIMENTAL SITES. Three vineyards were used for testing in 2011 and 2012. Vineyard 1, located near Salem, OR, was planted in 2009 to 'Pinot noir' (Vitis vinifera) grafted to 3309C rootstock (Vitis riparia $\times$ Vitis rupestris). Vines were spaced $4 \mathrm{ft}$ apart in row and $6 \mathrm{ft}$ between rows in north-south oriented rows, were spur pruned to a cordon system with a terminal arced cane at the last node position, and the canopy was vertically shoot positioned. This vineyard was used to test different aspects of the RIB extraction method in 2011 as the site was found to be severely infested with grape rust mites ( $>3000$ per leaf). The vineyard manager first observed leaves showing stippling symptoms in early July. The manager used the S\&S extraction method and a stereoscope to quantify grape rust mite populations at this vineyard. In addition, leaf samples were collected from Vineyard 1 to test the RIB method in midsummer (22 Aug.) and again in late summer (19 Sept.) of 2011 to examine the impact of canopy applications of sulfur or an insecticidal soap (see below) applied by the grower. Both bronzing and stippling were observed on leaves at this vineyard in 2011 , but no stunted shoots were found in Spring 2011 or 2012.

Vineyard 2, located in Dayton, OR, was planted in 2008 to 'Chardonnay' ( $V$. vinifera) grafted to Riparia Gloire rootstock ( $V$. riparia). Vines were spaced $5 \mathrm{ft}$ apart in row and $7 \mathrm{ft}$ between rows in north-south oriented rows, were cane pruned, and trained to a vertically shoot-positioned trellis system. Within this particular vineyard block, vines had moderate grape rust mite infestation (100 to 400 per leaf) throughout 2011. This site was used to relate leaf stippling symptoms with grape rust mite abundance (13 July 2011), and to test the utility of scouting for stippled leaves to identify grape rust mite presence (12 Sept. 2011). Grape rust mite populations on young shoots and leaves were also monitored in this vineyard over two growing seasons (2011 and 2012). Pesticide spray records for this site were provided by the vineyard manager from 2009 to 2012. Dormant canes with buds were also collected from this site to develop a blender method to examine grape rust mites overwintering in or around individual buds.
Vineyard 3 is a block within the same commercial vineyard as Vineyard 2, and they are located within $300 \mathrm{~m}$ of each other. This block was planted in 2009 to 'Syrah' ( $V$. vinifera) grafted to Riparia Gloire rootstock. Vines were spaced $5 \mathrm{ft}$ apart in row and $7 \mathrm{ft}$ between rows in northsouth oriented rows, cane pruned, and trained to a vertically shootpositioned trellis system. This vineyard was only used in 2012 to sample grape rust mites on young shoots after abnormally stunted shoots were noticed by the vineyard manager after budbreak. Young shoots were collected and compared from both Vineyard 2 and Vineyard 3 in 2012.

\section{Mite extraction methods}

SPRAY \& SIEVE. The S\&S method based on previous ethanol washing procedures (Pérez-Moreno and MorazaZorrilla, 1998; Zacharda et al., 1988) was initially used for quantifying grape rust mites on leaves and tissues. The method was modified by vigorously spraying the leaf surface with ethanol or isopropanol (at $70 \% \mathrm{v} / \mathrm{v}$ ) using a manual atomizer pump sprayer. The front and back of each leaf was held at a $45^{\circ}$ angle over a $25-\mu \mathrm{m}$ sieve while spraying with alcohol solution to retrieve grape rust mites and other fauna. Contents of the sieve were transferred to a petri dish using an alcohol solution and examined under a stereoscope at $\times 40$ magnification. Gridded petri dishes were used when high numbers of mites $(>200)$ were found in a given sample, and a random subset of grids was counted and a multiplication factor used to calculate the total grape rust mites present. The three most commonly found fauna groups included grape rust mites, predatory mites (Typhlodromus pyri), and western flower thrips, and each group was counted in all samples extracted.

RINSE IN BAG. A second method, RIB, was developed that used readily available supplies. This method was evaluated and compared with the S\&S method. Individual leaves were collected in the field into individual resealable plastic bags. The RIB method was used to extract all fauna from single leaves or single shoots directly in the bag in which they were collected. Leaf blades were cut into $\approx 2 \mathrm{~cm}^{2}$ pieces and returned to the original collection bag. For small shoots, leaves were cut from the main 
stem and the main stem was cut into $\approx \mathrm{l} \mathrm{cm}$ lengths using small scissors and returned to the collection bag. A total of $50 \mathrm{~mL}$ of either $35 \%$ or $70 \%$ ethanol or isopropanol was added to the bag while rinsing the scissors. The bag was resealed and shaken vigorously for $30 \mathrm{~s}$. A small hole was cut from the corner of the bag and the rinsate was decanted into a petri dish leaving the plant tissues behind. Grape rust mites, predatory mites, and western flower thrips were counted under a stereoscope, as described earlier. The small volume of alcohol used for this method eliminates the sieve step and resulted in less alcohol use as compared with the S\&S method. The only specialized equipment required for this method is a stereoscope with a magnification range of at least $\times 40$, although $\times 100$ is preferable.

BLENDER METHOD-YOUNG sноoтs. Because leaf tissue is covered with trichomes, and young shoots can have very high trichome density early in the season (Liakopoulos et al., 2006), we anticipated that the RIB method would not efficiently extract grape rust mites from young shoots. A standard laboratory blender was used to disrupt tissues and collect fauna released on a series of sieves. After mites were extracted from young shoots using the RIB method, plant tissues and any fauna remaining in the bag were transferred to a blender cup with 50 to $100 \mathrm{~mL}$ of $70 \%$ ethanol, blended for $10 \mathrm{~s}$ on high speed using a blender (Waring Laboratory Science, Winsted, CT), and transferred to a series of sieves (500, $250,125$, and $25 \mu \mathrm{m})$. The material on each sieve was thoroughly washed with cold tap water, transferred with $70 \%$ ethanol to petri dishes, and fauna therein were counted under a stereoscope. This method resulted in more plant debris in the rinsate and required more time to sort through debris under the stereoscope.

BLENDER METHOD-DORMANT BuDs. The RIB method was not effective for assessing grape rust mites in buds during dormancy because they were most often located under bud scales or deep within the leaf scar area below dormant buds. The blender method was used to assess grape rust mites present in and around dormant buds. Single buds were removed from the cane by cutting into the woody tissue $\approx 2$ to $3 \mathrm{~mm}$ surrounding and below each bud and included the necrotic tissue around the leaf scar. The bud was then bisected longitudinally, placed in the blender with $50 \mathrm{~mL}$ of $70 \%$ ethanol, blended on high speed for $10 \mathrm{~s}$, and fauna were collected on 125- and 25- $\mu \mathrm{m}$ sieves.

Visual Counts. Direct visual counts were performed by carefully examining young shoots, leaves, or buds under a stereoscope, gently pulling back trichomes, and separating tiny new leaves with forceps. For dormant buds, the bud scales were sequentially removed to examine underlying tissues. This method was useful in determining the location of grape rust mites in different tissues, but it was difficult to generate accurate counts and was exceptionally time-consuming.

\section{Sampling methods and tests performed}

COMPARISON OF VINE SYMPTOMS TO GRAPE RUST MITES USING THE RIB AND S\&S METHOD. About 150 individual leaves were randomly collected from the middle to upper canopy from numerous locations throughout Vineyard 1 on 22 Aug. 2011. Roughly $30 \%$ to $40 \%$ of the leaves in this vineyard displayed either bronzing or stippling symptoms. Each leaf was placed in a single plastic bag upon collection, placed in a cooler, transported to the laboratory, and stored at $4{ }^{\circ} \mathrm{C}$. After initial inspection under a stereoscope to confirm presence of grape rust mites, leaves were sorted and placed into three categories based upon leaf symptoms: bronzed, stippled, or asymptomatic. Twenty bronzed leaves were randomly selected and ten were extracted using either the RIB method or S\&S method with $70 \%$ isopropanol to compare methods. Another set of 24 bronzed leaves were then extracted with the RIB method using either $35 \%$ or $70 \%$ isopropanol $(n=12)$, to test if concentration of alcohol influenced grape rust mite extraction. A third set of 20 leaves was extracted with $35 \%$ isopropanol using the RIB method to determine difference in fauna between leaves showing either stippling or bronzing symptoms $(n=10)$. Grape rust mites, predatory mites, and western flower thrips were quantified in all extracts. Extraction efficiency of the RIB method was determined from five individual bronzed leaves with high grape rust mite numbers and extracting three consecutive times with fresh 35\% isopropanol $(50 \mathrm{~mL})$ for each leaf. Leaves were carefully examined under a stereoscope after the third extraction in the bag confirming that no grape rust mites remained on the leaves.

Association OF SYMPTOMATIC LEAVES TO GRAPE RUST MITES. Leaf samples were collected on 13 July and 12 Sept. 2011 from Vineyard 2 to test the relationship of leaf stippling symptoms with the presence of grape rust mites. On 13 July, $\approx 100$ fully expanded leaves were randomly collected from midcanopy throughout the vineyard, placed in individual resealable plastic bags, placed in a cooler for transit, and stored at $4{ }^{\circ} \mathrm{C}$ until analysis. Individual leaves were rated for the severity of stippling damage using a category scale from 0 to $4(0=$ no symptoms, $1=10 \%$ to $20 \%$ leaf surface with pinhole stippling, $2=20 \%$ to $40 \%$ leaf surface with pinhole stippling, $3=$ more than $40 \%$ leaf surface with pinhole stippling and clear zones coalescing and forming zones $1-2 \mathrm{~mm}$ in size, $4=$ more than $50 \%$ leaf surface with pinhole stippling and clear zones coalescing and forming zones $>2 \mathrm{~mm}$ in size). Leaves were backlit and photographed. Grape rust mites and other fauna were extracted from leaves using the S\&S method and counted under a stereoscope. A minimum of eight leaves in each symptom category were extracted from the July samples. Leaves were again collected in September by using two collection methods. On 12 Sept., $\approx 30$ fully expanded leaves from the mid to upper canopy were collected at random, and another 30 leaves were collected based on the presence of stippling symptoms observed in the field. Leaves from both collection methods were individually bagged and transported to the laboratory as described earlier. Fourteen leaves of each type were randomly selected and extracted using the RIB method with $35 \%$ isopropanol. Grape rust mites, predatory mites, and western flower thrips were counted in all extracts.

RIB METHOD EFFICACY ON YOUNG shoots. Young shoots were collected from Vineyard 2 on 30 Apr. 2012, 
$\approx 15 \mathrm{~d}$ after budbreak. Both normal shoots and those that were stunted were selected throughout the block. Stunted shoots in Vineyard 2 lacked the pubescent symptoms found earlier in heavily grape rust mite-infested vineyards, but were visibly shorter than most in the vineyard. Shoots from Vineyard 3 were collected on 2 May 2012, $\approx 10$ d after budbreak. Both normal shoots and those that were stunted and highly pubescent were selected. All shoots were individually bagged and handled as mentioned earlier. Individual shoots were first measured for length and examined under a stereoscope to quantify the number of grape rust mites, predatory mites, and western flower thrips within a 5-min time limit. Immediately thereafter, fauna were extracted using the RIB method with $50 \mathrm{~mL}$ of $70 \%$ ethanol. Following RIB extraction, each shoot was transferred to a blender and remaining fauna were extracted using the blender method for shoots. The number of grape rust mites, predatory mites, and western flower thrips was subsequently counted. The percent recovery of grape rust mites using the RIB method was calculated based on the total count of grape rust mites from the RIB method plus blender method for each shoot.

COMPARISON OF BLENDER METHOD TO VISUAL COUNTS ON DORMANT BUDS. Dormant canes were collected in Vineyard 2 from four different locations within the vineyard on 13 Jan. 2012. Two canes were randomly selected from each vineyard location, transported back to the laboratory, and a single cane from each vineyard location was randomly assigned to visual examination or blender extraction for a total of four canes used for each method. The blender method could not be compared with visual counts on the same buds because buds were destroyed during the process. The number of grape rust mites was recorded for each bud along the cane from the basal most bud (node 1 ) to the 14th node. No time limit was applied when counting grape rust mites under the stereoscope for buds.

A CASE STUDY OF GRAPE RUST mite SEAsonal populations. Population estimates of grape rust mites at a moderately infested block at Vineyard 2 were carried out over 2 years (2011 and 2012). Whole shoots were collected shortly after budbreak (19 May 2011 and 30 Apr. 2012) when shoots were 7 to $12 \mathrm{~cm}$ long, and leaves were sampled during early summer (13 July 2011 and 14 June 2012) and again before (13 Sept. 2011 and 6 Sept. 2012) and after fruit harvest $(6$ Oct. 2011 and 8 Oct. 2012). At each sample date, $\approx 50$ young shoots or 50 single leaves were collected at random throughout the canopy and vineyard block without scouting for symptoms. Sampling was conducted in this way to avoid any bias because of the presence of stippling symptoms and to best estimate grape rust mite abundance in the vineyard. Grape rust mites were extracted using the RIB method with $35 \%$ isopropanol from 20 single shoots or 20 leaves per sampling date. Sulfur was applied multiple times to the entire vineyard in each year for dual use as a miticide and fungicide, although spray applications varied by year. In 2011, wettable sulfur (Thiosperse $^{\circledR}$ 80; Continental Sulfur Co., Kilgore, TX) was applied to vines on 17 Apr., 3 May, 27 June, 3 Aug., and 17 Aug. at a rate of $4 \mathrm{lb} /$ acre actual sulfur. In addition, the first two sprays in 2011 (17 April and 3 May) included lime sulfur (28\% calcium polysulfide; OR-CAL, Junction City, OR) at $0.2 \mathrm{gal} /$ acre rate. In 2012, wettable sulfur was applied on 24 Apr., 7 May, 29 May, 9 July, 17 July, 26 July, and 6 Aug. at the same rate as 2011, but no lime sulfur was used in 2012 .

A CASE STUdy ObServing THE IMPACT FROM SPRAYS ON GRAPE RUST MITES. The impact of midseason miticides to control grape rust mites was tested commercially by the vineyard manager at Vineyard 1 in 2011. Vines were sprayed with wettable sulfur (Microthiol Disperss ${ }^{\circledR}$ 80WP; United Phosphorus, King of Prussia, PA) at $5 \mathrm{lb} /$ acre actual sulfur along with an adjuvant (Vintre $\mathrm{Oil}^{\circledR}$; Oro Agro, Fresno, CA), or with potassium salts of fatty acids (M-Pede ${ }^{\circledR}$; Dow AgroSciences, Indianapolis, IN) at a rate of $0.75 \mathrm{gal} / \mathrm{acre}$ a.i. on $22 \mathrm{Aug}$. 2011. A 20 -row section of the vineyard was left as a nontreated control, receiving no sprays. The spray application was not spatially replicated, but prior sampling within each of the areas of the vineyard indicated high grape rust mite abundance. Fifteen leaves were randomly collected from the mid and upper canopy within each of the three treatment areas (sulfur, potassium salts of fatty acids, and nontreated), individually bagged, and transported to the laboratory on 19 Sept. 2011, $\approx 1$ month after spray application. Grape rust mites, predatory mites, and western flower thrips were quantified using the RIB method with 35\% isopropanol. Because significant leaf damage was observed during the grape-ripening phase, the impact of grape rust mites on vine photosynthesis was examined. Single leaf gas exchange was measured $3 \mathrm{~d}$ after sampling (22 Sept. 2011) by selecting both midcanopy (older) and upper canopy (younger) leaves that were either bronzed or asymptomatic in a $2 \times 2$ factorial design. Twelve sunexposed leaves were measured within each category (total of 48 leaves) using a portable photosynthesis system (6400 XTR; LI-COR Biosciences, Lincoln, NE) under clear, cloudless conditions in early afternoon (1350 to $1440 \mathrm{HR}$ ) using ambient sunlight $\left(P A R>1500 \mu \mathrm{mol} \cdot \mathrm{m}^{-2} \cdot \mathrm{s}^{-1}\right)$ with temperature $\left(30.6^{\circ} \mathrm{C}\right)$ and carbon dioxide $\left(\mathrm{CO}_{2}\right)$ control $(400 \mathrm{ppm})$.

STATISTICAL ANALYSIS. The number of grape rust mites, predatory mites, and western flower thrips extracted by various methods or numbers from visual counts on shoots, buds, or leaves, as well as the leaf area or shoot length data were analyzed by analysis of variance (ANOVA) or by the nonparametric Kruskal-Wallis test for those data that could not be transformed to satisfy variance assumptions for ANOVA. The statistical test used for a given dataset is indicated in the tables or figure legends, and effects were considered significant at $P \leq 0.05$. Means were compared using Tukey's honestly significant difference test when ANOVA was used or by Kruskal-Wallis multiple comparison tests at $95 \%$ confidence. Means are reported for each group of categorical data, except for the grape rust mite numbers associated with varying levels of leaf stippling symptoms at Vineyard 2 because these data were log-transformed to overcome homogeneity of variance assumptions before ANOVA. Back-transformed means and $95 \%$ confidence intervals are reported for these data.

\section{Results}

COMPARISON OF VINE SYMPTOMS TO GRAPE RUST MITES USING THE RIB AND S\&S METHOD. The RIB method 
was equally effective as the modified $S \& S$ method for extracting grape rust mites and predatory mites from single leaves at Vineyard 1 (Table 1). However, the RIB method extracted more western flower thrips than the S\&S method from leaves. There was no difference in the number of fauna extracted from leaves when comparing $35 \%$ to $70 \%$ isopropanol with the RIB method. Also, the numbers of grape rust mites or predatory mites on bronzed and stippled leaves were similar, although more western flower thrips were found on stippled leaves. Although we did not formally quantify the time needed to process samples with the RIB and S\&S methods, the RIB method took $\approx 50 \%$ less time to process samples than the $S \& S$ method. The RIB method was efficient in grape rust mite extraction even when samples were highly infested by grape rust mites. Assuming that all mites were extracted after three washes from five individual leaves, the average recovery of grape rust mites in the first wash was $85 \%$ (Fig. 1). Examination of leaves under the stereoscope after the third successive wash confirmed that no grape rust mites remained on these leaves, although it is likely that a few grape rust mites were not extracted or visually detected. About $20 \%$ of the leaves examined from Vineyard 1 had more than 5000 grape rust mites inhabiting a single leaf, causing significant visual symptoms of stippling and bronzing.

Association of SYMPTOMATIC LEAVES TO GRAPE RUST MITES. The number of grape rust mites increased with the severity of leaf stippling symptoms from 'Chardonnay' leaves collected in early summer (Fig. 2). Leaves with a severity rating of $1,2,3$, or 4 had mean grape rust mite numbers of $19,112,274$, and 568 , respectively. When Vineyard 2 leaves were sampled late in summer using stippling symptoms to guide leaf selection, about 5 -fold more grape rust mites per leaf were found compared with leaves collected at random ( $\mathrm{Ta}-$ ble 2). The numbers of western flower thrips and predatory mites were similar for collections of symptomatic and random leaf samples.

RIB METHOD EFFICACY ON YOUNG shoots. The number of grape rust mites extracted from normal shoots of 'Chardonnay' grapevines from

Table 1. Effect of extraction method, isopropanol concentration, and leaf symptoms on the mean number of fauna extracted from individual 'Pinot noir' grapevine leaves from Vineyard 1 on 22 Aug. 2011.

\begin{tabular}{lccc}
\hline Method/treatment & Grape rust mites & Predatory mites & $\begin{array}{c}\text { Western flower } \\
\text { thrips }\end{array}$ \\
\hline Rinse in bag method $^{\mathrm{z}}$ & 3576 & 7.6 & $4.5 \mathrm{a}^{\mathrm{y}}$ \\
Spray and sieve method $^{\text {Plevel }}$ & 3659 & 8.6 & $0.9 \mathrm{~b}$ \\
35\% Isopropanol & 0.931 & 0.862 & 0.008 \\
$70 \%$ Isopropanol & 3261 & 9.4 & 7.9 \\
Plevel $_{\text {Bronzed leaves }}^{\mathrm{x}}$ & 3914 & 8.1 & 11.1 \\
Stippled leaves $^{\text {Plevel }}$ & 0.461 & 0.762 & 0.452 \\
\hline
\end{tabular}

${ }^{\mathrm{z}}$ Bronzed leaves were used to compare extraction methods $(n=10)$.

${ }^{y}$ Means followed by a different letter for mites or western flower thrips within each test category differ based on Tukey's honestly significant difference test at $95 \%$ confidence.

${ }^{x}$ The rinse in bag method was used to compare isopropanol concentrations $(n=12)$ and leaves with different symptoms $(n=10)$.

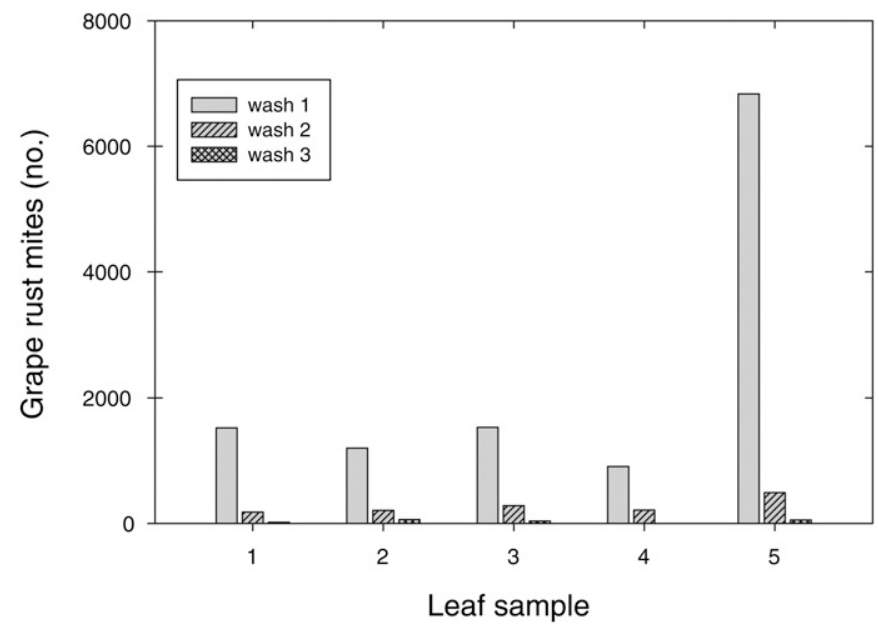

Fig. 1. Recovery of grape rust mites from five individual 'Pinot noir' grapevine leaves in three successive extractions of $50 \mathrm{~mL}(1.7 \mathrm{fl} \mathrm{oz})$ using the rinse in bag method with 35\% isopropanol. Leaves were collected from Vineyard 1 on 22 Aug. 2011.

Vineyard 2 in early Spring 2012 did not differ from the number found on stunted shoots for any of the methods tested (Table 3). Mean grape rust mite numbers were numerically higher on stunted shoots, but high variability was observed using all methods. The RIB and RIB + blender counts of grape rust mites were higher than direct counts. The number of predatory mites on normal shoots was greater than that on stunted shoots, although the number of western flower thrips did not differ among shoot types. The efficiency of grape rust mite extraction using the RIB method was generally high $(>68 \%)$ for shoots from Vineyard 2. Stunted 'Syrah' shoots (Fig. 3 ) collected from Vineyard 3 in Spring 2012 had significantly more grape rust mites than the normal shoots for each of the methods used (Table $3)$. The number of grape rust mites extracted using the RIB method or the combined total (RIB + blender) was $\approx 16$-fold greater in stunted shoots than in normal shoots. Stunted 'Syrah' shoots also had more western flower thrips as compared with normal shoots, but predatory mite numbers did not differ. The efficiency of grape rust mite extraction using the RIB method was lower for 'Syrah' shoots (35\% to $40 \%$ ) as compared with 'Chardonnay' shoots, most likely because of the greater number of trichomes present. 'Chardonnay' shoots were more glabrous and broke bud earlier in the season, leading to earlier shoot expansion and lower trichome density, presumably 


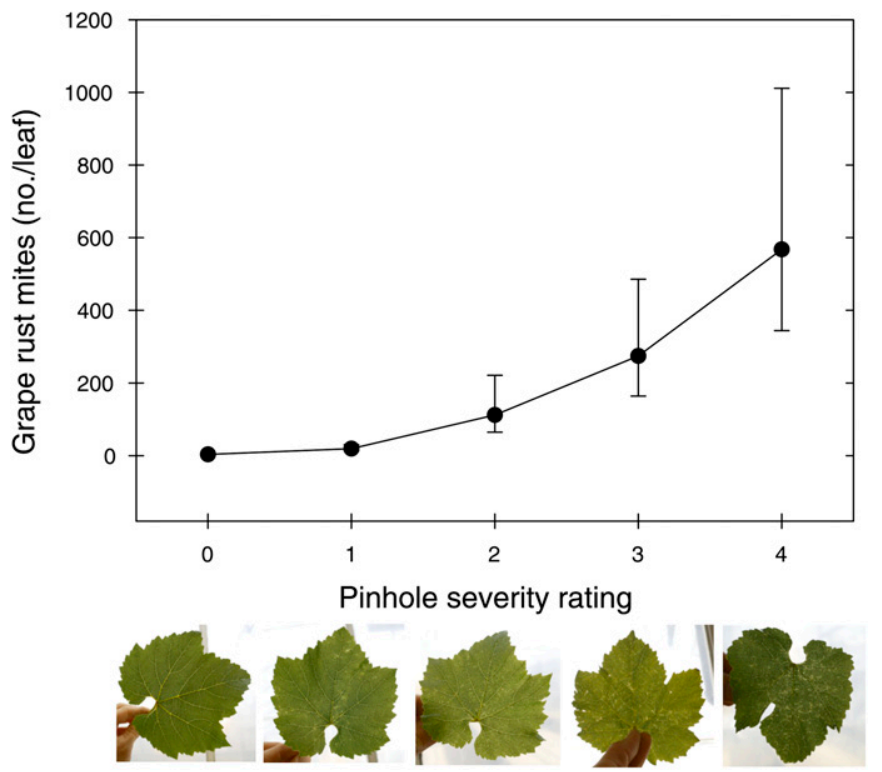

Fig. 2. Association between grape rust mites extracted from individual 'Chardonnay' grapevine leaves and leaf stippling symptoms in early summer. Leaf stippling severity was rated on a scale from 0 to 4 , and grape rust mites were extracted with $70 \%$ ethanol using the spray and sieve method. Data presented are back-transformed means and $\mathbf{9 5 \%}$ confidence limits from log-transformed data. Leaves were collected from Vineyard 2 on 13 July 2011.

Table 2. Effect of leaf sampling method on the mean number of fauna extracted from individual 'Chardonnay' grapevine leaves from Vineyard 2 on 12 Sept. 2011.

\begin{tabular}{lccc}
\hline & \multicolumn{2}{c}{ Leaf sampling method $^{\mathrm{z}}$} & \\
\cline { 2 - 3 } Variable & Symptomatic & Random & P level $^{\mathrm{y}}$ \\
\hline Stippling severity rating (0-4 scale) & $1.7 \mathrm{a}^{\mathrm{x}}$ & $0.5 \mathrm{~b}$ & $<0.001$ \\
Grape rust mites & $3070 \mathrm{a}$ & $594 \mathrm{~b}$ & $0.005^{*}$ \\
Predatory mites & 5.8 & 4.6 & $1.000^{*}$ \\
Western flower thrips & 0.9 & 0.9 & 0.988 \\
Leaf area $\left(\mathrm{cm}^{2}\right)^{\mathrm{w}}$ & 99 & 110 & 0.425 \\
\hline
\end{tabular}

${ }^{\mathrm{z}}$ Leaves were collected by selecting leaves with stippling symptoms or at random. Samples were extracted using the rinse in bag method with $35 \%$ isopropanol.

y Probability values followed by * were derived from Kruskal-Wallis $(\mathrm{K}-\mathrm{W})$ analysis, all others from analysis of variance.

${ }^{x}$ Means followed by a different letter in a row differ based on Tukey's honestly significant difference test or K-W multiple range test at $95 \%$ confidence $(n=14)$.

${ }^{\mathrm{w}} 1 \mathrm{~cm}^{2}=0.1550$ inch $^{2}$.

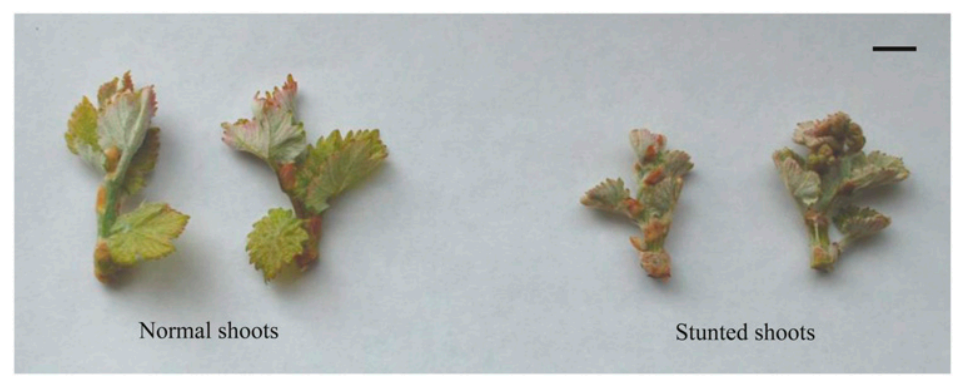

Fig. 3. Photographs of normal and stunted shoots of 'Syrah' grapevines collected from Vineyard 3 on 2 May 2013; bar = $1 \mathrm{~cm}(0.4$ inch $)$.

providing fewer areas of refuge for these cryptic mites.

COMPARISON OF BLENDER METHOD TO VISUAL COUNTS ON
DORMANT BUDS. The numbers of grape rust mites overwintering in or around single buds on dormant canes were highly variable with respect to bud position (Table 4). Relatively high numbers of grape rust mites were found in buds at any node along the total length of the dormant cane. The highest number of grape rust mites found in any single bud using the blender method was 483 . The blender method was most effective in estimating grape rust mites in buds, with 5 -fold greater numbers of grape rust mites found per bud compared with visual counts under the stereoscope. It should be noted that no time limit was applied when counting grape rust mites visually for buds, so the direct counts were not limited by observer time. Grape rust mites observed visually were often seen among the trichomes, at the base of the bud beneath the first few bud scales, or within the spongy sclerenchyma tissues around the leaf scar. The blender method was more time-consuming to obtain grape rust mite counts per sample than the RIB method used earlier for shoots or leaves because of extra plant debris released during the blending step. The high numbers of grape rust mites found in buds at this site did not lead to significant stunting of shoots observed in the following spring.

A CASE STUdy OF GRAPE RUST MITE SEASONAL POPULATIONS. The number of grape rust mites present and symptoms on 'Chardonnay' shoots and leaves from Vineyard 2 was quite different in 2011 than in 2012 (Fig. 4). These data were collected from random samples in the field so that the population estimates would not be biased by collecting shoots or leaves expressing symptoms related to grape rust mite feeding. In both years, the number of grape rust mites detected on newly emerging shoots was not different $(P>0.05)$. However in 2011, the grape rust mite population on leaves increased by early summer and continued to increase until mid-September. Postharvest sampling in October yielded relatively high numbers of grape rust mites on leaves. In 2012, the population of grape rust mites did not become established to any extent on leaves and no stippling symptoms were observed; the highest number per leaf in mid-June 2012 was 1.2 grape rust mites. In 2011 , the stippling symptoms were first observed on leaves in this vineyard $\approx 2$ weeks before bloom and throughout the rest of the growing season. Neither 
Table 3. Effect of extraction and enumeration method on the mean number of grape rust mites, and effect of shoot type on the mean number of fauna from individual young shoots of 'Chardonnay' grapevines from Vineyard 2 and 'Syrah' grapevines from Vineyard 3 in Spring 2012.

\begin{tabular}{|c|c|c|c|c|}
\hline \multirow[b]{2}{*}{ Vineyard/date } & \multirow[b]{2}{*}{ Variable } & \multicolumn{2}{|c|}{ Shoot type } & \multirow[b]{2}{*}{$P$ level $^{\mathrm{z}}$} \\
\hline & & Normal & Stunted & \\
\hline \multirow{4}{*}{$\begin{array}{l}\text { 'Chardonnay' / } 30 \text { Apr. } 201215 \mathrm{~d} \text { after } \\
\text { budbreak }(n=14)\end{array}$} & Grape rust mites-visual counts (no.) & $1.2 \mathrm{~B}^{\mathrm{y}}$ & $4.6 \mathrm{~B}$ & $0.082 *$ \\
\hline & Grape rust mites-RIB + blender method (no.) & $13.9 \mathrm{~A}$ & $71.8 \mathrm{~A}$ & 0.069 * \\
\hline & Grape rust mites recovered by RIB method (\%) & 81.0 & 68.8 & 0.233 \\
\hline & Predatory mites-RIB method (no. $)^{\mathrm{w}}$ & $3.3 \mathrm{a}^{\mathrm{v}}$ & $0.7 \mathrm{~b}$ & $0.001^{*}$ \\
\hline \multirow{5}{*}{$\begin{array}{l}\text { 'Syrah' } / 2 \text { May } 201210 \mathrm{~d} \text { after } \\
\text { budbreak }(n=10)\end{array}$} & Grape rust mites-visual counts (no.) & $1.1 \mathrm{~b}, \mathrm{~B}$ & $42.8 \mathrm{a}, \mathrm{B}$ & $<0.001^{*}$ \\
\hline & Grape rust mites-RIB method (no.) & $9.4 \mathrm{~b}, \mathrm{AB}$ & $161.1 \mathrm{a}, \mathrm{AB}$ & $<0.001^{*}$ \\
\hline & Grape rust mites-RIB + blender method (no.) & $29.3 \mathrm{~b}, \mathrm{~A}$ & $482.1 \mathrm{a}, \mathrm{A}$ & $<0.001^{*}$ \\
\hline & Grape rust mites recovered by RIB method (\%) & 39.9 & 34.8 & 0.293 \\
\hline & Predatory mites-RIB method (no.) & 0.2 & 0.3 & 0.627 \\
\hline
\end{tabular}

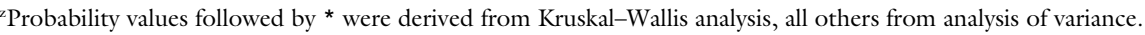

${ }^{y}$ Means for grape rust mites determined by each method followed by a different capital letter within a column differ based on Kruskal-Wallis (K-W) multiple range test at $95 \%$ confidence.

${ }^{x} \mathrm{RIB}=$ rinse in bag.

"Predatory mites and western flower thrips were recorded for the RIB method only.

${ }^{\vee}$ Means for shoot type followed by a different small case letter within a row differ based on Tukey's honestly significant difference test or K-W multiple range test at $95 \%$ confidence.

${ }^{u} \mathrm{l} \mathrm{cm}=0.3937$ inch

stunted pubescent shoots (early season) nor leaf bronzing symptoms (late season) were observed at Vineyard 2 in either year.

A CASE STUdy OBSERVING THE IMPACT FROM SPRAYS ON GRAPE RUST MITES. A midsummer sulfur application applied at Vineyard 1 reduced grape rust mites on leaves in midSeptember by $\approx 80 \%$, although vines treated with potassium salts of fatty acids did not differ from the nontreated vines (Table 5). The vineyard manager also examined hundreds of leaves throughout this block on 29 Aug. 2011 and recorded a decrease in grape rust mite counts in the sulfurtreated plot but no decrease in the plot treated with potassium salts of fatty acids or the nontreated plot. Leaf bronzing was visible by late Summer/ early Fall of 2011, and was less prevalent in the sulfur-treated plot. Rates of single leaf photosynthesis were reduced $(P<0.01)$ by $44 \%$ in bronzed leaves as compared with nonsymptomatic leaves measured on 22 Sept. 2011, although location in the canopy (mid vs. upper) was not significant. The assimilation rate of nonsymptomatic and bronzed leaves was (mean \pm SE) $9.4 \pm 1.0$ and $5.3 \pm 1.0 \mu \mathrm{mol} \mathrm{CO} \mathrm{CO}_{2}$ fixed per square meter per second, respectively.

Grape rust mites were observed at Vineyard 1 by the vineyard manager in early Spring 2012 during budbreak and post-budbreak. As a result, the vineyard manager increased sulfur use to control grape rust mites as part of his fungicide spray program throughout the 2012 growing season. This resulted in decreased grape rust mite populations and no leaf symptoms in 2012 , as determined by the vineyard manager.

\section{Discussion}

The primary purpose of this research was to develop a user-friendly method to monitor grape rust mites on leaves and shoots throughout the year. The RIB method was quick and effective for monitoring grape rust mites on individual leaves (Tables 1 , 2 , and 5). Supplies needed for the RIB method are readily available at grocery or variety stores, except for a moderate quality stereoscope required to examine extracts. High numbers of grape rust mites were recovered in the first wash from single leaves (Fig. 1), and both ethanol and isopropanol were effective in recovering grape rust mites from leaves. Reducing the concentration of alcohol from $70 \%$ to $35 \%$ was equally as effective for extracting grape rust mites from leaf surfaces (Table l). The RIB method is easier for viticulturists or IPM consultants to accomplish than the modified S\&S method. Using a single leaf with the RIB method is also advantageous for three reasons: 1) fewer laboratory supplies are needed, 2 ) little plant debris is extracted from single leaves that allows for more accurate enumeration under a stereoscope, and 3) a lower volume of alcohol is used.

The RIB method was not as efficient in extracting grape rust mites from young shoots with numerous trichomes (Table 3 ) as it was for fully expanded leaves (Fig. 1). Difficulty extracting eriophyoid mites from plant surfaces with a high trichome density is well known (Duso and Vettorazzo, 1999; Monfreda et al., 2010). The lower efficiency of grape rust mite extraction using the RIB method for young 'Syrah' shoots compared with young 'Chardonnay' shoots was most likely because of the higher trichome density on the former shoots (Table 3 ). However, the RIB method was less time-consuming than visual counts or blender extraction. For diagnosing grape rust mite presence associated with early season shoot stunting, all three methods tested, including visual counts under a stereoscope, gave similar results (Table 3 ). On the basis of 4 years of visual observations under a stereoscope across 15 vineyards, we have had little difficulty diagnosing when 
Table 4. Effect of extraction and enumeration method on the mean number of grape rust mites associated with individual dormant buds of 'Chardonnay' grapevines from Vineyard 2 on 13 Jan. 2012.

\begin{tabular}{lcccc}
\hline $\begin{array}{l}\text { Bud } \\
\text { position }^{\mathbf{y}}\end{array}$ & \multicolumn{2}{c}{ Grape rust mites (no/bud) } & Buds analyzed & \\
\cline { 2 - 3 } Visual counts $^{\mathbf{z}}$ & Blender counts & P level \\
\hline 1 & 6.8 & 144.0 & 4 & 0.236 \\
2 & 5.0 & 182.0 & 4 & 0.191 \\
3 & 30.2 & 168.5 & 4 & 0.309 \\
4 & 35.0 & 116.0 & 4 & 0.375 \\
5 & 13.3 & 64.0 & 4 & 0.191 \\
6 & 18.5 & 61.8 & 4 & 0.166 \\
7 & 51.0 & 35.0 & 4 & 0.885 \\
8 & 14.0 & 37.8 & 4 & 0.375 \\
9 & 11.0 & 38.5 & 4 & 0.245 \\
10 & 2.0 & 18.3 & 4 & 0.081 \\
11 & 0.3 & 14.5 & 4 & 0.091 \\
12 & 18.8 & 92.5 & 4 & 0.166 \\
13 & 11.1 & 80.5 & 4 & 0.248 \\
14 & 2.5 & 26.0 & 4 & 0.663 \\
Total (all buds) & $16.0 \mathrm{~b}^{\mathrm{x}}$ & $77.1 \mathrm{a}$ & 56 & $<0.001$ \\
Range of values & $0-147$ & $0-483$ & & \\
\hline
\end{tabular}

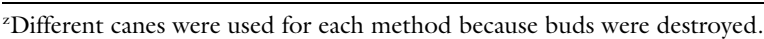

'Bud position is from the basal end of the cane.

${ }^{x}$ Means followed by a different letter in a row differ based on Kruskal-Wallis multiple range test at 95\% confidence.

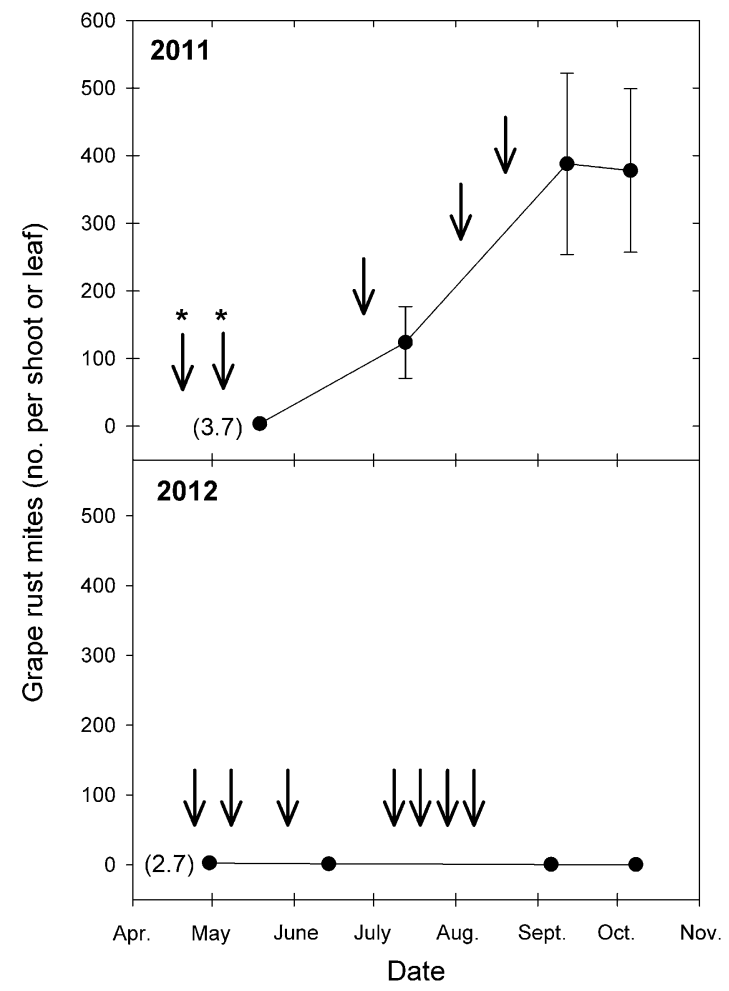

Fig. 4. Seasonal population of grape rust mites found on individual 'Chardonnay' grapevine shoots and leaves in 2011 and 2012 extracted using the rinse in bag method. The first value in each year indicated within parentheses represents the number of grape rust mites per shoot, all other values are per leaf $(n=20)$. Data are means $( \pm S E)$, and both years are shown at same scale. Arrows indicate the time of wettable sulfur applications $\left[4 \mathrm{lb} / \mathrm{acre}\left(4.5 \mathrm{~kg} \cdot \mathrm{ha}^{-1}\right)\right.$ actual sulfur] and an asterisk $\left({ }^{*}\right)$ indicates that lime sulfur was included in a given spray at $0.2 \mathrm{gal} /$ acre (1.9 $\left.\mathrm{L} \cdot \mathrm{ha}^{-1}\right)$. Shoots or leaves were collected from Vineyard 2. early spring shoot stunting was caused by grape rust mites, as high numbers of mites (always >200) were quickly found upon examination under a stereoscope.

Using the extraction methods proved helpful in confirming grape rust mite presence in symptomatic vineyards. In the young 'Syrah' shoots from Vineyard 3 where shoot-stunting symptoms were evident, we found $\approx 160$ grape rust mites per shoot using the RIB method, which equated to nearly 500 grape rust mites per stunted shoot in total (RIB + blender method). This is consistent with grape rust mite numbers found with restricted spring growth research from Australia and Europe (Bernard et al., 2005; Duso and de Lillo, 1996), but well above the proposed threshold of nine grape rust mites per shoot reported by Walton et al. (2010). Further work will be required to establish distinct management thresholds for grape rust mites. However, because both shoot expansion and mite populations are in constant flux early season, this goal may prove difficult to accomplish.

Scouting for visual symptoms such as leaf stippling in grapevine canopies can be a useful first step in identifying emerging grape rust mite outbreaks. The presence of leaf stippling was the first symptom expressed in grape rust mite-infested experimental vines (nursery cuttings), newly planted vineyards, and established vineyards across the region, even before spring shoot stunting had occurred typically the following year. A clear association of grape rust mite numbers per leaf and stippling symptoms was shown in early summer (Fig. 2), and also at the end of summer (mid-September) when leaves collected at random were compared with leaves selected with stippling symptoms (Table 2). Leaf stippling was also found in all the vineyards sampled during summer months over the past 4 years where significant grape rust mite populations have been identified (R.P. Schreiner and P.A. Skinkis, unpublished data). Leaf stippling symptoms have been noted in other reports from Europe (Estación Fitopatolóxica do Areeiro, 2013; Vinograd, 2013). Late-season leaf bronzing symptoms that result from heavy grape rust mite infestations are well known (Baillod and Guignard, 1986; Duso et al., 
Table 5. Impact of wettable sulfur or potassium salts of fatty acids sprays from a nonreplicated case study on the mean number of fauna extracted from individual leaves of 'Pinot noir' grapevines from Vineyard 1 on 19 Sept. 2011.

\begin{tabular}{lccc}
\hline Treatment $^{\mathrm{z}}$ & $\begin{array}{c}\text { Grape rust } \\
\text { mites (no.) }\end{array}$ & $\begin{array}{c}\text { Predatory } \\
\text { mites (no.) }\end{array}$ & $\begin{array}{c}\text { Western flower } \\
\text { thrips (no.) }\end{array}$ \\
\hline Wettable sulfur & $818 \mathrm{~b}^{\mathrm{y}}$ & $2 \mathrm{~b}$ & 4 \\
Potassium salts of fatty acids & $2958 \mathrm{a}$ & $7 \mathrm{a}$ & 3 \\
Nontreated & $4447 \mathrm{a}$ & $5 \mathrm{a}$ & 5 \\
Plevel & 0.009 & 0.002 & 0.226 \\
\hline
\end{tabular}

${ }^{\mathrm{z}}$ Leaves were collected at random 1 mo. after spray application and extracted using the rinse in bag method $(n=$ 15). Wettable sulfur $=5 \mathrm{lb} /$ acre $\left(5.6 \mathrm{~kg} \cdot \mathrm{ha}^{-1}\right)$ actual sulfur, potassium salts of fatty acids $=0.75 \mathrm{gal} / \mathrm{acre}(7.0$ $\left.\mathrm{L} \cdot \mathrm{ha}^{-1}\right)$ a.i., nontreated $=$ no miticide application.

${ }^{y}$ Means followed by a different letter within a column differ based on Tukey's honestly significant difference test at $95 \%$ confidence.

2010), but this symptom may not occur in all vineyards. The simultaneous occurrence of both stippling and bronzing symptoms on leaves, as seen at Vineyard 1 in 2011, clearly indicates a high grape rust mite population. At Vineyard 1, the bronzing was more apparent on the older leaves although stippling was more noticeable on younger, upper canopy leaves, suggesting that bronzing requires greater exposure time to grape rust mites in order to develop. It should be noted that western flower thrips can cause a similar type of shoot and leaf damage on grapevines, but the symptoms can be distinguished by the larger size of translucent zones on the leaf and the formation of necrotic lesions on the leaf surface mid- to late season. These larger clear zones on leaves caused by western flower thrips feeding are typically located near intersections of major leaf veins and often near the petiole. In comparison, grape rust mites produce smaller stippling clear zones (pinhole size) and they are typically scattered across much of the leaf surface (Fig. 2).

The high number of grape rust mites on leaves (>3000 per leaf) observed at the severely infested Vineyard 1 in 2011 was similar to the highest levels of grape rust mites reported in Europe (Duffner et al., 2001; Duso and de Lillo, 1996; Pérez-Moreno and Moraza-Zorrilla, 1998). The populations at Vineyard 2 in 2011, which we consider a moderate infestation $(\approx 400$ grape rust mites per leaf), were higher than those reported in earlier work conducted in Oregon (Walton et al., 2007, 2010) and Europe (Hluchý and Pospisil, 1992) where crop yield was reported to be reduced. No evidence of crop loss or stunted shoots was found in Vineyard 1 or Vineyard 2 in 2011 or in 2012 (data not shown), suggesting that damage thresholds for this pest in a given vineyard may vary considerably. A decline in grape rust mite populations on leaves at the end of summer was not apparent in either Vineyard 1 or Vineyard 2 in 2011 as reported in other studies (Duso and de Lillo, 1996; Pérez-Moreno and Moraza-Zorrilla, 1998). Similar to our findings, Walton et al. (2007) reported that leaf populations of grape rust mites did not decrease at the end of the summer. These results suggest that a large migration of grape rust mites to overwintering sites near the base of shoots or trunks of vines may not occur as early in summer as suggested earlier (Pérez-Moreno and MorazaZorrilla, 1998) or may not occur consistently in all vineyards.

Analysis of single leaf gas exchange at Vineyard 1 in late Summer 2011 showed that photosynthesis was reduced by $44 \%$ in bronzed leaves as compared with asymptomatic leaves. The rate of photosynthesis of bronzed grapevine leaves caused by grape rust mites did not differ from nonsymptomatic leaves in Germany (Rees and Scruft, 1994). However, leaf photosynthesis and transpiration were reduced in apple (Malus $\times$ domestica) leaves infested by the apple rust mite [Aculus schlechtendali (Spieser et al., 1998)]. Our data suggest that high populations of grape rust mites can reduce photosynthesis and explain perhaps why reduced sugar accumulation in berries has occurred in severely infested vineyards (Hluchý and Pospisil, 1992). Low sugar concentration in berries was reported by the vineyard manager of Vineyard 1 in 2011.

Appropriately timed canopy sulfur applications appear to be an effective tool in managing grape rust mite populations during the growing season. The divergent grape rust mite populations quantified over two seasons at Vineyard 2 are likely related to increased sulfur use in 2012 (Fig. 4). The two canopy sulfur applications aimed toward controlling grape rust mites during wooly bud stage before budbreak in 2011 (containing lime sulfur and wettable sulfur) did not appear to control grape rust mites that year. This could be due to the 2 -month time lapse between subsequent sulfur applications, allowing a small population to multiply rapidly by early summer. In 2012, the grape rust mite population never accrued on leaves during summer, which appears to be due to the more timely use of sulfur by the vineyard manager for dual use as a miticide and fungicide to control grape powdery mildew (Erisyphe necator). Sulfur applications were more numerous and spray intervals were shorter in 2012 than in 2011 (Fig. 4). A single midsummer sulfur application at Vineyard 1 also reduced grape rust mites on leaves by $\approx 80 \%$, although potassium salts of fatty acids did not reduce populations (Table 5). Seasonal populations of grape rust mites studied over 4 years in a Spanish vineyard support our findings to some degree (PérezMoreno and Moraza-Zorrilla, 1998). They reported the lowest population of grape rust mites on leaves when three closely timed sulfur applications were applied to the canopy in early summer, although higher populations were found in the years where only one or two sulfur applications were made.

These findings combined with experiences from multiple grower's in Oregon using wettable sulfur indicate that sulfur is a promising tool for reducing grape rust mite populations. The utility of sulfur for controlling grape rust mites is also supported by our observations of where grape rust mite outbreaks have typically occurred in the region. Grape rust mite problems and symptoms of shoot stunting, leaf stippling, or leaf bronzing have most often been found in newly planted vineyards that do not have a fully implemented spray program or in older (producing) vineyards where sulfur use has been largely replaced by synthetic fungicides for grape powdery mildew control in the Willamette Valley.

Estimating grape rust mite presence in winter may also be useful for 
early season management, before symptoms are visible. The blender method used in this study was more effective than visual counts under a stereoscope for estimating grape rust mites overwintering in or around dormant buds. The number of grape rust mites found in buds was much greater than earlier reports (Bernard et al., 2005; Walton et al., 2007). However, despite the high numbers of grape rust mites observed in buds from Vineyard 2 during Winter 2012, only low numbers of grape rust mites were found on shoots the following spring. Therefore, a decline of grape rust mites in late winter/early spring had occurred because of unknown factors. It should be noted that no early season (wooly bud or post-budbreak) lime sulfur was applied in 2012 to explain this population decline. It is likely that high numbers of grape rust mites per bud in the winter are necessary to reliably predict if shoot stunting will occur the following spring. On the basis of Vineyard 2 data, an average of 77 grape rust mites per bud in winter did not cause shoot stunting the following spring. Understanding the biotic and abiotic factors that impact the survival of grape rust mites from midwinter to early spring within grapevine buds is an important area for future research.

\section{Literature cited}

Baillod, M. and M. Guignard. 1986. Nouveaux dégâts de l'acariose bronze et du court-noué parasitaire dus à Calepitrimerus vitis (Nalepa) (Acari, Eriophydae) en 1984 et 1985. Revue Suisse de Viticulture Arboriculture Horticulture 18:285-288.

Bernard, M.B., P.A. Horne, and A.A. Hoffmann. 2005. Eriophyoid mite damage in Vitis vinifera (grapevine) in Australia: Calepitrimerus vitis and Colomerus vitis (Acari: Eriophyidae) as the common cause of the widespread 'Restricted Spring Growth' syndrome. Expt. Appl. Acarol. 35:83-109.

Bhatti, M.A., K. Al-Khatib, and R. Parker. 1997. Wine grape (Vitis vinifera) response to fall exposure of simulated drift from selected herbicides. Weed Technol. 11:532-536.

Cook, J.A. 1966. Grape nutrition, p. 777-812. In: N.F. Childers (ed.). Nutrition of fruit crops. Somerset Press, Somerville, NJ.

Duffner, K., G. Schruft, and R. Guggenheim. 2001. Passive dispersal of the grape rust mite Calepitrimerus vitis (Nalepa) 1905: (Acari, Eriophyoidea) in vineyards. J. Pest Sci. 74:1-6.

Duso, C. and E. de Lillo. 1996. Grape, p. 571-582. In: E.E. Lindquist, M.W. Sabelis, and J. Bruin (eds.). Eriophyoid mites: Their biology, natural enemies and control. Elsevier, Amsterdam, The Netherlands.

Duso, C. and E. Vettorazzo. 1999. Mite population dynamics on different grape varieties with or without phytoseiids released (Acari: Phytoseiidae). Expt. Appl. Acarol. 23:741-763.

Duso, C., M. Castagnoli, S. Simoni, and G. Angeli. 2010. Impact of eriophyoids on crops: Recent issues on Aculus schlechtendali, Calepitrimerus vitis, and Aculops lycopersici. Expt. Appl. Acarol. 51:151-168.

Estación Fitopatolóxica do Areeiro. 2013. Calepitrimerus vitis - Acariose first symptoms. 7 Aug. 2013. <http://www.efadip.org/en/servicios/galeria/index.asp >.

Fennel, A. 2004. Freezing tolerance and injury in grapevines. J. Crop Improv. 10:201-235.

Hluchý, M. and Z. Pospišil. 1992. Damage and economic injury levels of eriophyid and tetranychid mites on grapes in Czechoslovakia. Expt. Appl. Acarol. 14:95-106.

Liakopoulos, G., D. Nikolopoulos, A. Klouvatou, K.-A. Vekkos, Y. Manetas, and G. Karabourniotis. 2006. The photoprotective role of epidermal anthocyanins and surface pubescence in young leaves of grapevine (Vitis vinifera). Ann. Bot. (Lond.) 98:257-265.

McNally, P.S., C. Fogg, J. Flynn, and J. Horenstein. 1985. Thrips damage in Chenin blanc grapes. Calif. Agr. 39:23-24.

Monfreda, R., M. Lekveishvili, R. Petanovic, and J.W. Amrine. 2010. Collection and detection of eriophyoid mites. Expt. Appl. Acarol. 51:273-282.
Pérez-Moreno, I. and M.L. MorazaZorrilla. 1998. Population dynamics and hibernation shelters of Calepitrimerus vitis in the vineyards of Rioja, Spain, with a description of a new eriophyid extraction technique (Acari: Eriophyidae). Expt. Appl. Acarol. 22:215-226.

Rees, P. and G. Scruft. 1994. Einfluss der sommerlichen blatt-berostung durch die kräuselmilbe der rebe (Calepitrimerus vitis [Nal.]) auf den chlorophyll-gehalt und die photosynthase. Wein-Wissenschaft 49:168-169.

Spieser, F., B. Graf, P. Walther, and J. Noesberger. 1998. Impact of apple grape rust mite (Acari: Eriophyiidae) feeding on apple leaf gas exchange and leaf color associated with changes in leaf tissue. Environ. Entomol. 27:1149-1156.

Vinograd. 2013. Mite grape leaf: Calepitrimerus vitis Nalepa [Nal, Keifer]. 7 Aug. 2013. <http://vinograd.info/spravka/ slovar/klesch-vinogradnyi-listovoi.html>.

Walton, V.M., A.J. Dreves, D.H. Gent, D.G. James, R.R. Martin, U. Chambers, and P.A. Skinkis. 2007. Relationship between grape rust mites Calepitrimerus vitis (Nalepa), bud mites Colomerus vitis (Pagenstecher) (Acari: Eriophydae) and short shoot syndrome in Oregon Vineyards. Intl. J. Acarol. 33:307-318.

Walton, V.M., A.J. Dreves, L.B. Coop, G.V. Jones, and P.A. Skinkis. 2010. Developmental parameters and seasonal phenology of Calepitrimerus vitis (Acari: Ariophyidae) in wine grapes of western Oregon. Environ. Entomol. 39:20062016.

Westphal, E. and D.C.M. Manson. 1996. Feeding effects on host plants: Gall formation and other distortions, p. 231242. In: E.E. Lindquist, M.W. Sabelis, and J. Bruin (eds.). Eriophyoid mites: Their biology, natural enemies and control. Elsevier, Amsterdam, The Netherlands.

Winkler, A.J., J.A. Cook, W.M. Kliewer, and L.A. Lider. 1974. General viticulture. University of California Press, Berkeley, CA.

Zacharda, M., O. Pultar, and J. Muška. 1988. Washing technique for monitoring mites in apple orchards. Expt. Appl. Acarol. 5:181-183. 